\title{
Final Manufacturing Process of Front Side Metallisation on Silicon Solar Cells Using Conventional and Unconventional Techniques
}

\author{
Leszek Adam Dobrzański - Małgorzata Musztyfaga* - Aleksandra Drygała \\ Institute of Engineering Materials and Biomaterials, Silesian University of Technology, Poland
}

\begin{abstract}
The paper presents the results of the investigation of the front electrode manufactured using two silver pastes (PV 145 manufactured by Du Pont and another based on nanopowder experimentally prepared) on monocrystalline silicon solar cells in order to reduce contact resistance. The aim of the paper was a comparison between a conventional and an unconventional method to improve the quality of forming electrodes of silicon solar cells. The Screen Printing (SP) method is the most widely used contact formation technique for commercial silicon solar cells. Selective Laser Sintering (SLS) is a modern manufacturing technique, which uses a high power $\mathrm{CO}_{2}$ laser to melt or sinter metal powder particles into a mass that has the desired three-dimensional shape, in precisely defined areas. The whole process is controlled by a program that is used for micro-processing. An innovative aspect of this method is the application of a nano silver paste to create the seed layer of the front electrode using the SLS method.

The topography of both co-fired in the infrared belt furnace and melted/sintered in the Eosint M250 Xtended device equipped with C02 laser were studied. Contacts were investigated using confocal laser scanning microscope (CLSM 5) and a scanning electron microscope (SEM) with an energy dispersive X-ray (EDS) spectrometer for microchemical analysis. Both surface topography and a cross section of the front electrodes were studied using SEM microscope. Phase composition analyses of the chosen front electrodes were done using the XRD method delineated in this paper. Front electrodes were formed on the surface with a different morphology from the solar cells. The median size of the pyramids was measured using the atomic force microscope (AFM). Resistance of the front electrodes was measured using the Transmission Line Model (TLM).
\end{abstract}

Keywords: electrical properties, solar cell, selective laser sintering, screen printing

\section{INTRODUCTION}

The main focus of this paper was to study the manufacture of the front side metallization of solar cells. Many different methods have been applied to improve the electrical properties of front metallization. The photovoltaic market for silicon solar cells has been growing strongly over the past few years. Scientists are pushed to develop quicker some methods and technologies by the growth, at the same time, achieving both an improvement in efficiency and a reduction in the production costs of photovoltaic cells. Metallization is one of the key process steps in the manufacture of high efficiency solar cells. Fig. 1 presents some methods of manufacturing metal contacts at the front and back surfaces of solar cells [1] to [5].

The aim of the paper was a comparison of a conventional and an unconventional method to improve the quality of forming electrodes on silicon solar cells. The Screen Printing (SP) method is the most widely used contact formation technique for commercial silicon solar cells. Screen printing is performed on both the front and back sides of solar cell (Fig. 2). Each of the screen printing processes can be divided into three major steps [4] to [6]:

1. Overprinting a collection of back contacts $(\mathrm{Al} / \mathrm{Ag})$ and drying,

2. Overprinting a front electrode $(\mathrm{Ag})$ and drying,

3. Co-firing both front and back metal contacts.

\begin{tabular}{|c|c|c|}
\hline FRONT METAL CONTACT & BACK METAL CONTACT & FRONT AND BACK METAL CONTACTS \\
\hline Laser pad welding & Laser fired contact & Screen printing \\
\hline Selective laser sintering & Emitter wap through & Photolithography \\
\hline Light-induced electroplating & Metal wap through & Single and double sided buried \\
\hline Metal aerosol jetting & Metallisation wap around & contacts \\
\hline Pad printing & Interdigitated back contact & \\
\hline
\end{tabular}

Fig. 1. Methods of producing electrical contacts on solar cells [4] and [5]

*Corr. Author's Address: Institute of Engineering Materials and Biomaterials, Silesian University of Technology,

Konarskiego St. 18a, Gliwice, Poland, malgorzata.musztyfaga@polsı.pl 
Selective Laser Sintering (SLS) is a modern manufacturing technique, which uses a high power $\mathrm{CO}_{2}$ laser to melt or sinter metal powder particles into a mass that has a desired three-dimensional shape in precisely defined areas. The whole process is controlled by a program that is used for microprocessing. Process technology for the generation of front contacts by SLS is shown in Fig. 3 [4] and [5].

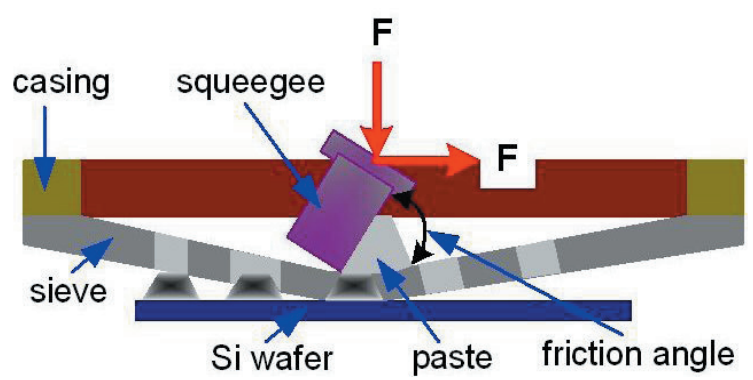

Fig. 2. The screen printing method [4] to [6]

\section{EXPERIMENTAL PROCEDURE}

The studies were carried out on monocrystalline silicon wafers produced by Deutsche Solar AG Germany. The material properties of the silicon used in this paper are presented in Table 1. The SLS method was used on wafers with a thickness $\sim 330 \mu \mathrm{m}$, whereas the SP method and co-firing in the furnace was used on wafers with a thickness of $\sim 230 \mu \mathrm{m}$.

The silver powder with the following granulation: 70,60 and $40 \mathrm{~nm}$ was applied during the preliminary investigations in order to select both the optimal granulation and the powder. Finally, the nanopowder was applied in investigations based on metallographic observations of front electrodes manufactured using the SLS method. The selection of elements in the contact layer of the solar cell is presented in Table 2. The selection of the chemical composition of the front contact was carried out by experiment and mixtures were prepared using a mechanical mixer. The technology used to produce the solar cell was developed in the Institute of Metallurgy and Materials Science in Krakow, Poland. The process sequence for manufacturing solar cells into different surface morphologies of silicon (100) is presented in Fig. 4.

Table 1. Basic properties of silicon

\begin{tabular}{ccc}
\hline Type & $p$ & $p$ \\
\hline Doped & boron & boron \\
\hline Thickness & $200 \pm 30 \mu \mathrm{m}$ & $330 \pm 10 \mu \mathrm{m}$ \\
\hline Area & $5 \times 5 \mathrm{~cm}$ & $5 \times 5 \mathrm{~cm}$ \\
\hline Resistivity & $1 \div 3 \Omega \bullet \mathrm{cm}$ & $\sim 1 \Omega \bullet \mathrm{cm}$ \\
\hline
\end{tabular}

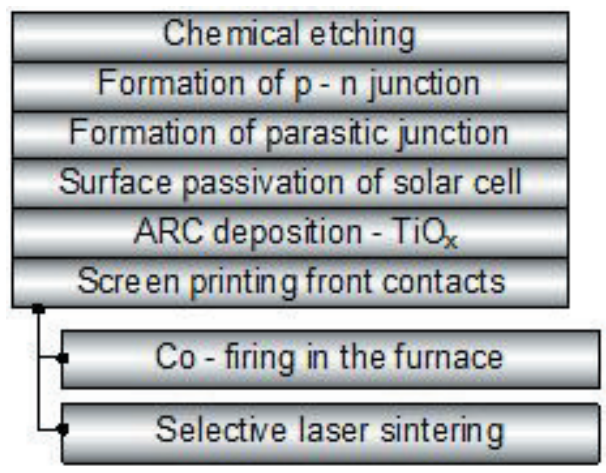

Fig. 4. The solar cell manufacturing process

The chemical procedure for cleaning the wafers is presented in Table 3. Emitter diffusion is one of the crucial steps in the manufacturing process of solar cells. The CVD method was used to apply the donor source. The emitter was generated at $840{ }^{\circ} \mathrm{C}$ for 40 minutes in an open quartz tube using $\mathrm{POCl} 3$ as the doping source. The parasitic junction was removed by means of a special teflon clamp in which the
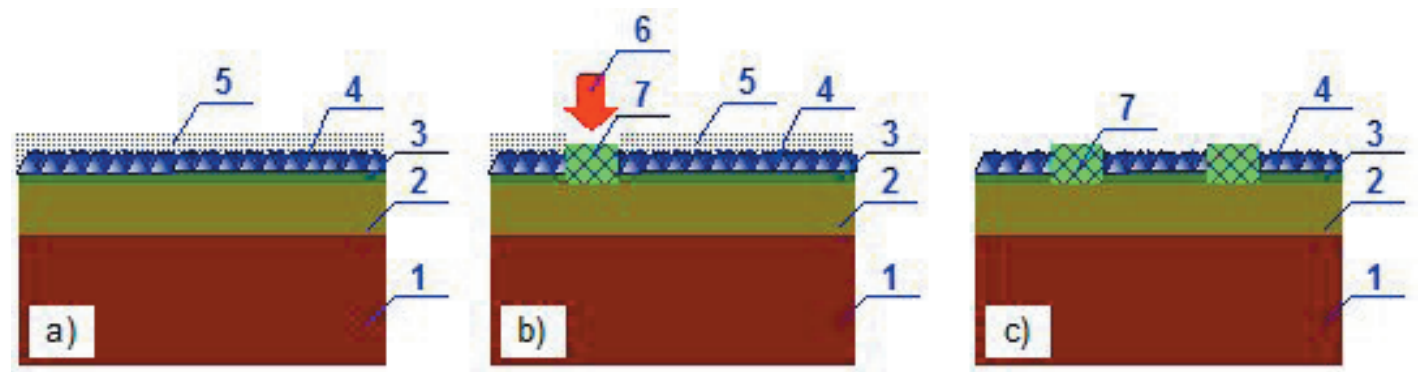

Fig. 3. Technology for the formation of front contacts by SLS: a) a metallic powder is coated on the wafer, b) a laser beam heats the powder locally and melts metal lines on the top of the wafer, c) the excess metallic powder is moved into the container ( 1 - $p$ type base material, 2 - $n$ type emitter, 3 - dielectric layer, 4 - textured layer, 5 - powder layer, 6 - passage of focus laser beam, 7 - SLS seed layers on the silicon surface) [4] and [5] 
silicon wafers were stacked using surface EVA foil separation.

Then the clap was immersed in $27 \% \mathrm{HF}: 45 \% \mathrm{HNO}_{3}: 27 \% \mathrm{CH}_{3} \mathrm{CO}-\mathrm{OH}$ solution in the volume ratio 3:5:3 for 40 seconds, followed by rising in $\mathrm{DIH}_{2} \mathrm{O}$. After diffusion, the wafers were covered by phosphorous-silicate glass $\left(\mathrm{xSiO}_{2} \cdot \mathrm{yP} \mathrm{O}_{5}\right)$, which was removed by immersion in a bath of $10 \%$ HF for two minutes. Surface passivation $\left(\mathrm{SiO}_{2}\right)$ took place at $800{ }^{\circ} \mathrm{C}$ for 10 minutes in a controlled atmosphere containing both $\mathrm{O}_{2}$ and $\mathrm{N}_{2}$. Titanium dioxide $\left(\mathrm{TiO}_{\mathrm{x}}\right)$ as an antireflection coating was deposited by spraying at $300{ }^{\circ} \mathrm{C}$ with tetraethylorthotitanat $\left(\left(\mathrm{C}_{2} \mathrm{H}_{5} \mathrm{O}\right)_{4} \mathrm{Ti}\right)$ using purified air as a carrier gas. The important aspect of this paper is the fabrication of the front metallization (the test electrodes system). This front metallization (test electrodes system) was manufactured in order to describe the usefulness of silver pastes using two technologies and to evaluate the contact resistance of the metal-semiconductor junction. Two special test electrode systems were prepared by screen printing method (Fig. 5.):

- I sizes of the front paths were: $2 \times 10 \mathrm{~mm}$ (wide $\mathrm{x}$ length), distances between them were: $20,10,5$ and $2.5 \mathrm{~mm}$,

- II sizes of front paths were: $5 \times 10 \mathrm{~mm}$ (wide $\times$ length), distances between them were: 1, 2, 4 and $8 \mathrm{~mm}$.

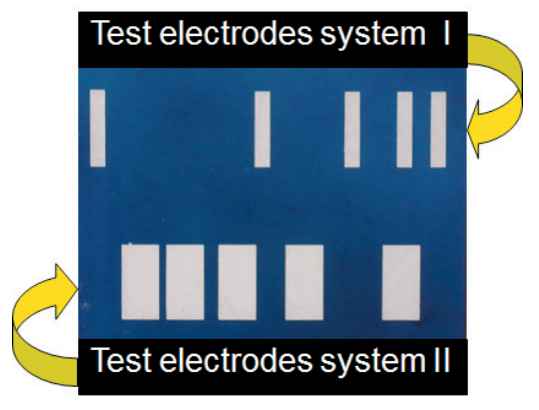

Fig. 5. Overview of test front electrode system

Many initial series for testing the solar cells were first prepared by laser micro-treatment in order to select conditions for the tests (the feed rate of passage of the laser beam and laser beam) and achieve the smallest resistance value of the connection zone between the electrode and the silicon substrate of the solar cell and a uniform structure. The most advantageous conditions of laser micro-treatment were selected based on the tests and metallographic observations. Table 4 shows the two chosen initial series of solar cell testing, which were then prepared by laser micro-treatment. Then laser micro-treatment conditions were selected for the test electrodes system I, II (Table 5) based on the results of the metallographic observations. Table 6 presents the general device data. In the case of co-firing in the conveyor belt IR furnace (Fig. 6), some solar cells were prepared using the test electrodes system I, II (Table 7). The belt IR furnace was equipped with fitted tungsten filament lamps, heating both the top and bottom of the belt.

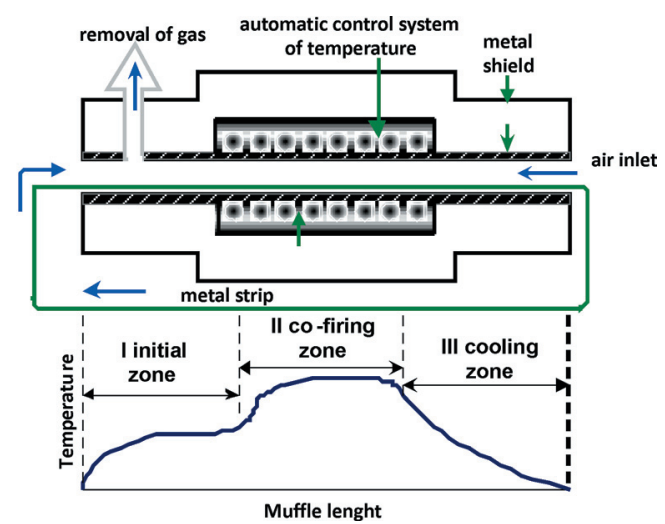

Fig. 6. A sketch of belt IR (an example) [7]

Table 2. Paste properties

\begin{tabular}{|c|c|c|c|c|}
\hline \multirow{2}{*}{$\begin{array}{l}\text { Paste } \\
\text { symbol }\end{array}$} & \multicolumn{3}{|c|}{$\begin{array}{l}\text { Mass concentration of elements } \\
\text { (prepared pastes) [\%] }\end{array}$} & \multirow{2}{*}{$\begin{array}{c}\text { Solar cells } \\
\text { with different } \\
\text { morphology* }\end{array}$} \\
\hline & $\begin{array}{c}\text { Basic } \\
\text { nanopowder }\end{array}$ & $\begin{array}{l}\text { Organic } \\
\text { carrier }\end{array}$ & $\begin{array}{l}\text { Ceramic } \\
\text { glaze }\end{array}$ & \\
\hline \multicolumn{5}{|c|}{ UNCONVECTIONAL METHOD } \\
\hline $\mathrm{A}$ & 83 & 15 & 2 & $1,2,3,4$ \\
\hline PV145* & - & - & - & $1,2,3,4$ \\
\hline \multicolumn{5}{|c|}{ CONVECTIONAL METHOD } \\
\hline $\mathrm{B}$ & 85 & 15 & - & 1,2 \\
\hline $\mathrm{C}$ & 88.40 & 11.60 & - & 3,4 \\
\hline PV145* & - & - & - & $1,2,3,4$ \\
\hline \multicolumn{5}{|c|}{$\begin{array}{l}\text { **Where: } \\
\text { 1. Non-textured surface with deposited } \mathrm{TiO}_{\mathrm{x}} \text { coating; } \\
\text { 2. Non-textured surface without deposited } \mathrm{TiO}_{\mathrm{x}} \text { coating; } \\
\text { 3. Textured surface with deposited } \mathrm{TiO}_{\mathrm{x}} \text { coating; } \\
\text { 4. Textured surface without deposited TiOx coating; } \\
\text { * commercial paste manufactured by the Du Pont company }\end{array}$} \\
\hline
\end{tabular}

Table 3. Chemical preparation of silicon wafers

\begin{tabular}{lc}
\hline \multicolumn{1}{c}{ Chemical operations } & Chemical recipe \\
\hline Washing in acetone & $\mathrm{CH} 3 \mathrm{COCH} 3$ \\
\hline Rinsing & $\mathrm{DlH} 2 \mathrm{O}$ \\
\hline Removal of distorted layer & $30 \% \mathrm{KOH}$ \\
\hline Rinsing & $\mathrm{DlH} 20$ \\
\hline $\begin{array}{l}\text { Removal of metallic } \\
\text { Contamination }\end{array}$ & $2 \% \mathrm{HCl}$ \\
\hline Removal of native oxide & $10 \% \mathrm{HF}$ \\
\hline Rinsing & $\mathrm{DlH} 20$ \\
\hline
\end{tabular}


Table 4. Initial conditions of laser micro-treatment for the test electrode system I, II of silicon wafers

\begin{tabular}{cccccc}
\hline Series & $\begin{array}{c}\text { Solar cell } \\
\text { surface }\end{array}$ & Paste symbol & $\begin{array}{c}\text { Feed rate of passage of } \\
\text { laser beam }(v),[\mathrm{mm} / \mathrm{s}]\end{array}$ & $\begin{array}{c}\text { Laser beam, } \\
(P)[\mathrm{W}]\end{array}$ & $\begin{array}{c}\text { Thickness of printed front electrode by } \\
\text { screen printing method }[\mu \mathrm{m}]\end{array}$ \\
\hline 1 & \multirow{2}{*}{$\begin{array}{c}\text { Chemically } \\
\text { cleaned }\end{array}$} & PV 145 & 50 to 200 & 8.1 to 37.8 & $15,40,60$ \\
\cline { 3 - 6 } & A & 50 to 200 & 21.5 to 48.6 & $15,35,70$ \\
\hline
\end{tabular}

Table 5. Conditions of laser micro-treatment testing electrodes of silicon solar cells with test electrode system I, II

\begin{tabular}{ccccccc}
\hline Series & $\begin{array}{c}\text { Solar cells with } \\
\text { different morphology* }\end{array}$ & Paste symbol & $\begin{array}{c}\text { The thickness of printed front electrode } \\
\text { by screen printing method, }[\mu \mathrm{m}]\end{array}$ & $\begin{array}{c}\text { The feed rate of passage the } \\
\text { laser beam }(v)[\mathrm{mm} / \mathrm{s}]\end{array}$ & $\begin{array}{c}\text { Laser beam }(\mathrm{P}) \\
{[\mathrm{W}]}\end{array}$ \\
\hline 1 & $1,2,3,4$ & $\mathrm{~A}$ & 15,35 & $37.8,40.5,43.2$ & 50 \\
\hline 2 & $1,2,3,4$ & $\mathrm{~A}$ & 15,35 & $48.5,51.3,54$ & 100 \\
\hline
\end{tabular}

*Where: 1. non textured surface with deposited $\mathrm{TiO}_{\mathrm{x}}$ coating; 2. non textured surface without deposited $\mathrm{TiO}_{\mathrm{x}}$ coating; 3 . Textured surface with deposited $\mathrm{TiO}_{\mathrm{x}}$ coating; 4. Textured surface without deposited $\mathrm{TiO}_{\mathrm{x}}$ coating

The following investigations were performed in this paper:

- The contact resistance $R_{c}$, specific contact resistance $\rho \mathrm{c}$, transfer length $\left(L_{T}\right)$ of front contact solar cell, and the use of the Transmission Line Model (TLM) method for the measuring position were determined at the Institute of Engineering Materials and Biomaterials.

- The topography of the silicon wafer with texture and antireflection coating (ARC) (this increases the absorption of sunlight and protects against pollution) were determined using an atomic force microscope (Park Systems XE 100) with an uncontacted trybe. The median size of the pyramids was also measured using this microscope.

- Phase composition analysis of the chosen front contacts using the XRD method.

- Microchemical analysis of the front chosen contacts using a scanning electron microscope equipped with an energy dispersive X-ray (EDS) spectrometer.

- The topography of both the surface and cross section of front contacts using:

- Zeiss Supra 35 scanning electron microscope using secondary electron detection with accelerating voltage in the range 5 to $20 \mathrm{kV}$.

- Zeiss confocal laser scanning microscope in which the source of light was a diode laser of approximately $25 \mathrm{~mW}$ emitting radiation with a wavelength of approx. $405 \mathrm{~nm}$. The thickness of the profile contact was determined on the basis of six median measurements.

\section{RESULTS AND DISCUSSION}

Based on the metallographic observations (Fig. 7), it was found that is not possible to apply silver pastes to deposit front electrodes (about regular shape and uniform thickness) using EOSINT M 250 Xtended device with SLS technology. Fig. 8a presents test electrode system I deposited using PV145 paste and selectively laser sintered. The observations revealed the occurrence of grains of diversified size and shape, similar to the electrode structure from the same paste before its laser micro-treatment (Fig. 8b), total overbaking, and evaporation of the electrode with increasing laser beam power. Based on the graphs, which present the resistance - distance relationship for the contacts involving parameters: $\rho_{c}$ (the specific contact resistance), $L_{T}$ (a track of current impact), and $R_{c}$ (contact resistance) (Fig. 9), the specific contact resistance defines not only the real joint zone of contact with the Si substrate, but the regions directly under and below surface of phase separation. The specific contact resistance of the front contact was calculated from formula in the literature, but other parameters like $R_{c}$ and $L_{T}$ were calculated from the linear regression. Contact resistance was measure using the TLM method, which consists of a direct current $(I)$ measurement and voltage $(U)$ measurement between any two separate contacts. In this paper, results were obtained for the specific contacts resistance of the front electrode for a given value of current $(10,30$ and $50 \mathrm{~mA}$ ) depending on the determined conditions of both the laser micro-treatment samples and the co-firing samples in the furnace. Fig. 9 presents an example of the series of test samples co-fired from the PV 145 paste in the temperature range of 830 to $920{ }^{\circ} \mathrm{C}$ onto a silicon solar cell with an ARC layer and without texture for a current value of $10 \mathrm{~mA}$.

Based on the electrical properties investigations using the TLM method in the first series, it was found that the smallest specific contact resistance values of the test electrodes system I, II are respectively 0.17 to $0.57 \Omega \cdot \mathrm{cm}^{2}, 0.53$ to $1.63 \Omega \cdot \mathrm{cm}^{2}$ for solar cells with 
different morphologies. The minimum value of the specific contact resistance was obtained for the test electrodes system I, II $\left(0.17 \Omega \cdot \mathrm{cm}^{2} ; 0.53 \Omega \cdot \mathrm{cm}^{2}\right)$ with a median thickness of $35 \mu \mathrm{m}$ onto substrate without texture and without $\mathrm{TiO}_{\mathrm{x}}$ coating using an applied laser beam of $37.8 \mathrm{~W}$ and a $50 \mathrm{~mm} / \mathrm{s}$ feed rate of passage of the laser beam.

Based on the electrical properties investigations using the TLM method in the second series it was found that the smallest specific contact resistance of the test electrode system I, II are respectively 0.01 to $0.77 \Omega \cdot \mathrm{cm}^{2}, 0.68$ to $2.82 \Omega \cdot \mathrm{cm}^{2}$ for solar cells with different morphologies.

Table 6. Technical specification of Eosint M 250 Xtended device

\begin{tabular}{cc}
\hline Laser $\mathrm{CO}_{2}$ & $200 \mathrm{~W}$ \\
\hline Feed rate of passage the laser beam & max. $3.0 \mathrm{~m} / \mathrm{s}$ \\
\hline Output laser beam & $270 \mathrm{~W}$ \\
\hline Diameter of laser beam & $300 \mu \mathrm{m}$ \\
\hline Wavelength & $10640 \mathrm{~nm}$ \\
\hline Shielding gas & nitrogen \\
\hline
\end{tabular}

The minimum value of the specific contact resistance was obtained for the test electrodes system I $\left(0.01 \Omega \cdot \mathrm{cm}^{2}, P=51.3 \mathrm{~W}\right)$, II $\left(0.68 \Omega \cdot \mathrm{cm}^{2}, P=48.6\right.$ W) about median thickness $35 \mu \mathrm{m}$ onto the substrate without texture and without $\mathrm{TiO}_{\mathrm{x}}$ coating with an applied feed rate of passage of the laser beam of 100 $\mathrm{mm} / \mathrm{s}$.

The thickness of the test electrodes was determined by checking the height profile of the threedimensional surface topography measured using the confocal laser scanning microscope (Fig. 10).

Table 7. Conditions of co-firing in the furnace test electrodes systems I,Il for silicon solar cells

\begin{tabular}{|c|c|c|c|c|}
\hline \multirow{2}{*}{ Series } & \multirow{2}{*}{$\begin{array}{c}\text { Paste } \\
\text { symbol }\end{array}$} & \multicolumn{3}{|c|}{ Temperature $\left[{ }^{\circ} \mathrm{C}\right]$} \\
\hline & & Zone I & Zone II & Zone III \\
\hline \multirow{5}{*}{1} & \multirow{5}{*}{$B, C$} & \multirow{5}{*}{530} & \multirow{5}{*}{570} & 830 \\
\hline & & & & 860 \\
\hline & & & & 890 \\
\hline & & & & 920 \\
\hline & & & & 945 \\
\hline \multirow{4}{*}{2} & \multirow{4}{*}{ PV 145} & \multirow{4}{*}{530} & \multirow{4}{*}{570} & 830 \\
\hline & & & & 860 \\
\hline & & & & 890 \\
\hline & & & & 920 \\
\hline
\end{tabular}

Based on these series, it was found that silicon substrate morphology has a huge influence on obtaining a minimal resistance value of the electrodes selectively laser sintered from paste A. The minimal resistance value is greater for the substrate with texture than for the one without texture, which is probably connected to the occurrence of mpty areas under the contacts, since the median thickness of the pyramids' textured surface for $\mathrm{Si}(100)$ is in the range from 3 to $9 \mu \mathrm{m}$. The antireflection coating prevents the reflection of rays of sunshine and a loss of energy, as well as creating a barrier to the connection zone, what has an influence on increasing resistance between an electrode layer and a silicon substrate. The thickness of the deposited layer has an influence on the structure of the obtained electrode layer and the resistance value of the resistance electrode. It was found that SLS testing contacts with a median thickness of about $35 \mu \mathrm{m}$ present both well adhering and condensing layers to the silicon substrate.

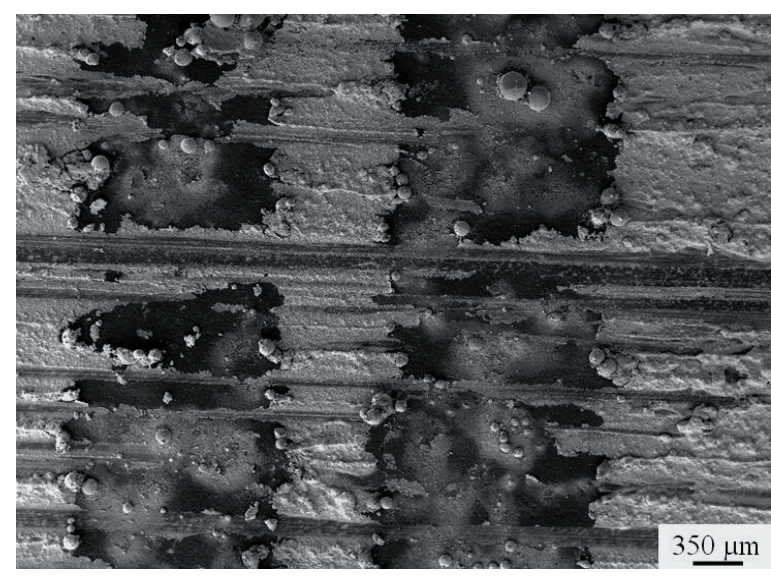

Fig. 7. Surface topography of front electrodes system I layer deposited from paste $A$ on the silicon substrate and laser sintered where $v=100 \mathrm{~mm} / \mathrm{s}$ and $P=32.4 \mathrm{~W}$

Based on the electrical properties investigations using the TLM method it was found that the smallest specific contact resistance is obtained in a second series of test electrodes system I, II formed from the PV 145 paste. In the temperature range from 860 to $920{ }^{\circ} \mathrm{C}$ the minimum value of the specific contact resistance of the test electrode system I, II is equal to 1.08 to $2.73 \Omega \cdot \mathrm{cm}^{2} ; 0.48$ to $1.33 \Omega \cdot \mathrm{cm}^{2}$ for solar cells with different morphologies. The highest range of specific contact resistance was found in the first series for front contacts made from C, PV 145 pastes. In the temperature range from 860 to $945{ }^{\circ} \mathrm{C}$ the minimum value of the specific contact resistance of test electrodes system I, II is equal to 1.83 to $86.81 \Omega \cdot \mathrm{cm}^{2}$; 1.12 to $71.63 \Omega \cdot \mathrm{cm}^{2}$ for solar cells with different morphologies. Electrical properties investigations using the TLM method confirm that the resistance paste decreases as the co-firing temperature of 


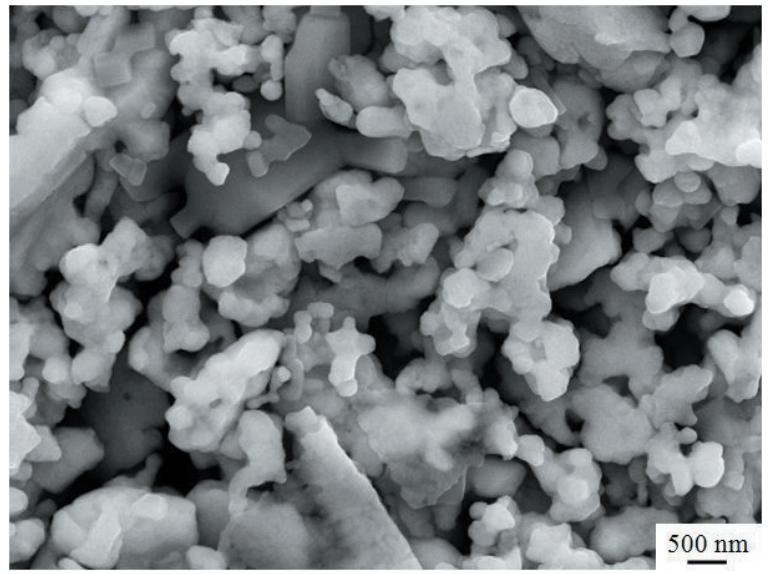

a)

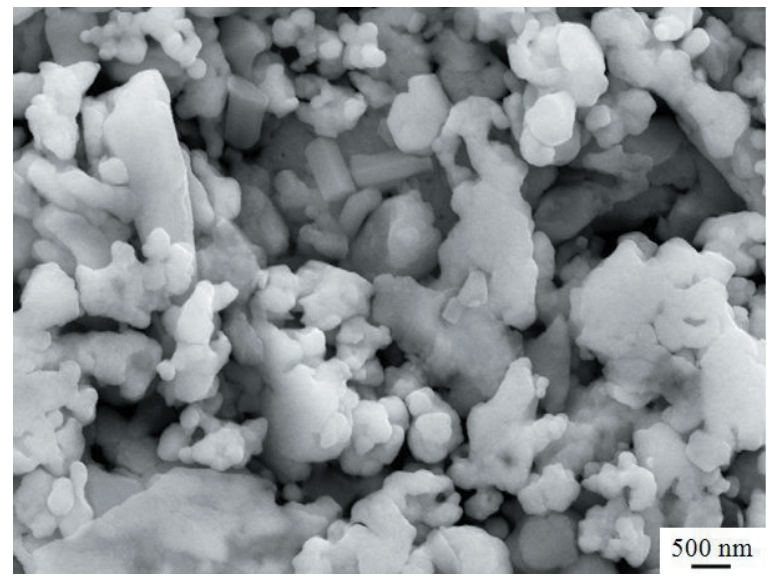

b)

Fig. 8. Surface topography of the front electrode system I layer deposited by screen printing from PV 145 paste onto the silicon substrate: a) not sintered, b) SLS with $v=50 \mathrm{~mm} / \mathrm{s}$ and $P=32.4 \mathrm{~W}$

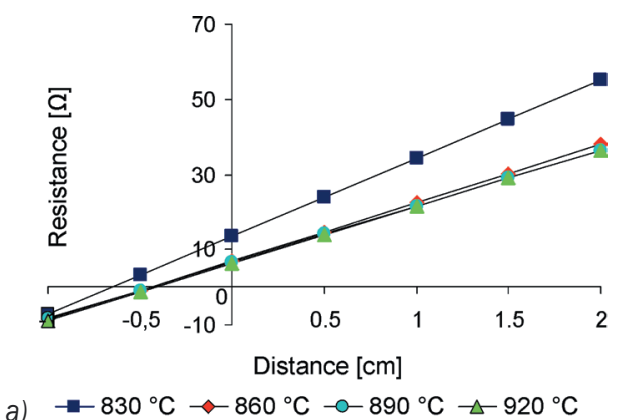

a) $\rightarrow-830^{\circ} \mathrm{C} \rightarrow-860^{\circ} \mathrm{C}-0-890^{\circ} \mathrm{C} \triangle 920^{\circ} \mathrm{C}$

b)

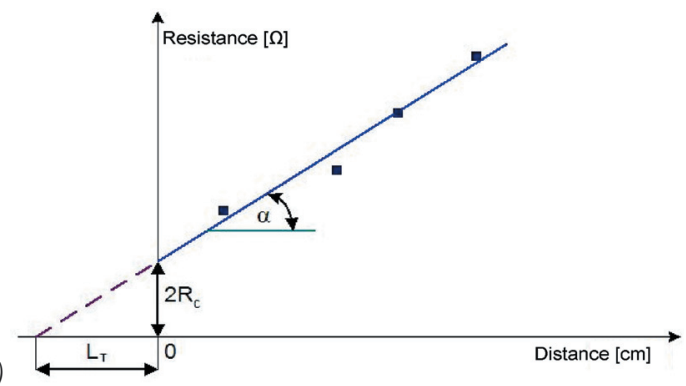

Fig. 9. a) An example of plot of resistance versus contact distance for the determination of contact parameters ( $L_{T}$ - a track of current impact) and $R c$-contact resistance, slope $=R_{p} / z, R_{p}$ - sheet resistance, $Z$ - contact length); b) typical graphic method from the literature used to determine factors [9] and [10]
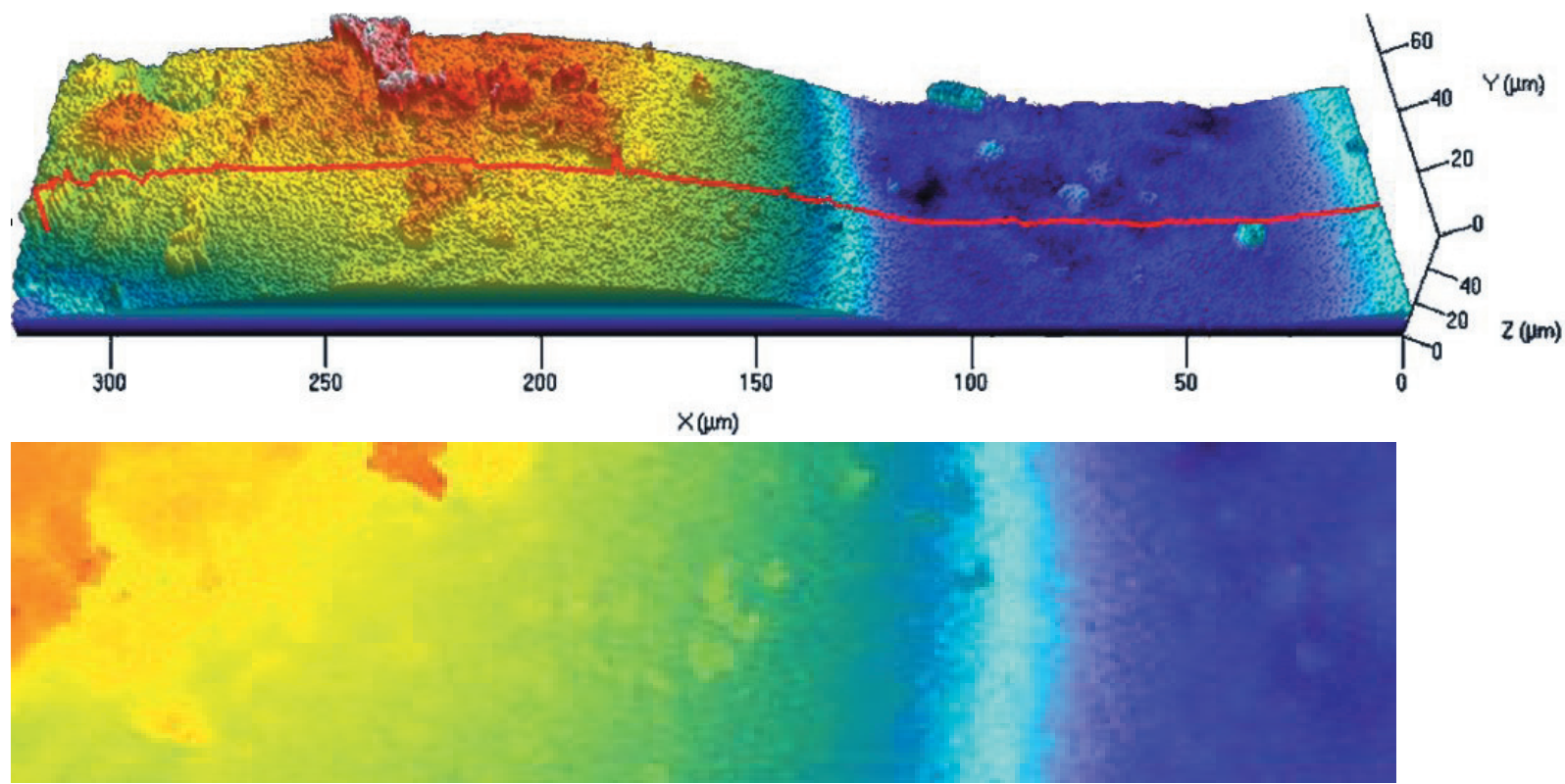

Fig. 10. Image of three- and two- dimensional surface topography (CLSM) of front electrode system I from paste A onto the Si substrate without texture or ARC layer by laser micro-machining 
electrode increases, this is caused by the decreasing resistance connection between metallic grains. The contact resistance was found to grow with increasing temperature, which was probably caused by melted silver molecules [7], which formed huge agglomerates or where voids would develop under the contacts in textured surfaces.

The contact layers from the preformed PV 145 paste create many homogenous connections with the silicon substrate, while contact layers from the $\mathrm{C}$, PV 145 pastes create point connections. The stability of electrical measurements using the TLM method guaranteed a median thickness of $35 \mu \mathrm{m}$ of the test electrodes system in the case of paste A, however in a case of the PV 145 paste this influence was not confirmed.

The thickness of the test electrodes co-fired at the highest temperatures with PV 145 and of the test electrodes sintered with a selective laser from the A paste decreases slightly versus the thickness of the electrodes before sintering. As a result of SEM investigations, the examined test front electrodes sintered using a selective laser reveal a diverse crosssection thickness of between $570 \mathrm{~nm}$ to $2.3 \mu \mathrm{m}$.

The topographies of the silicon wafers with texture and an ARC layer were observed using an atomic force microscope.. The median thickness of the pyramids was determined by atomic force microscope and found to to be equal to $4 \mu \mathrm{m}$ (Fig. 11).

The qualitative analysis of phase composition (Fig. 12) carried out using the X-ray diffraction method confirms that on the electrodes from sintered pastes, the layers contain the phase Ag, which was generated in congruence with the assumptions (Fig. 13). The presence of reflexes from the SI phase present in the substrate materials was demonstrated in the X-ray diffractograms obtained with the use of the Bragg-Brentano technique.

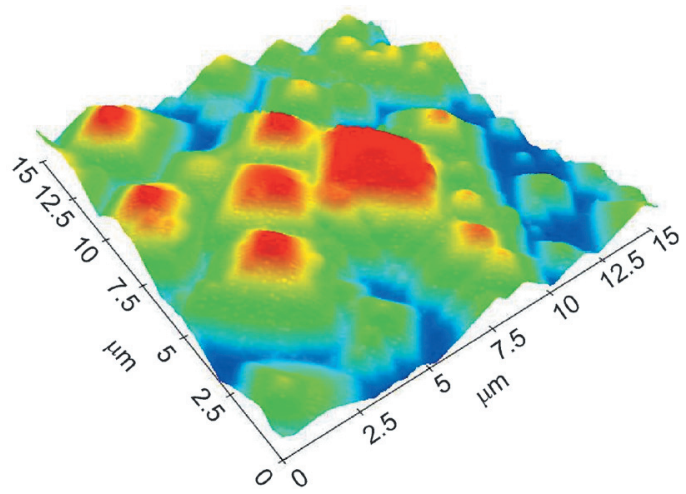

Fig. 11. The topography of monocrystalline silicon wafer with texture (an example)

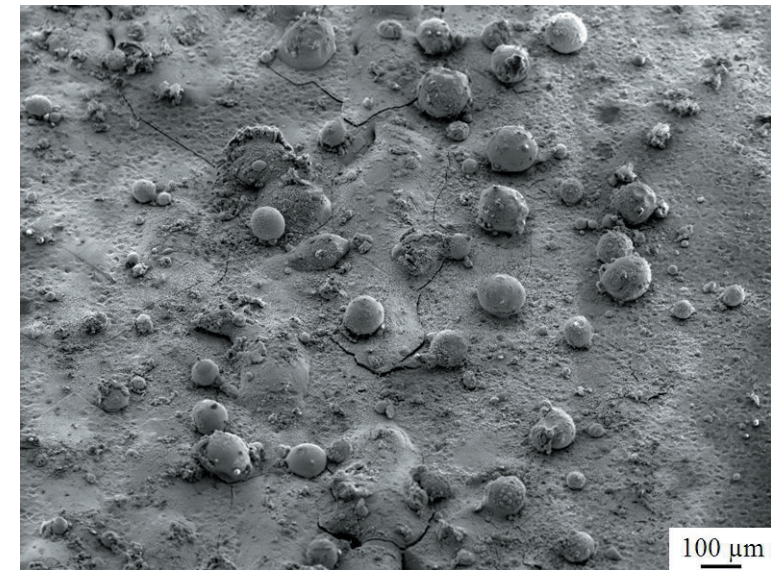

a)

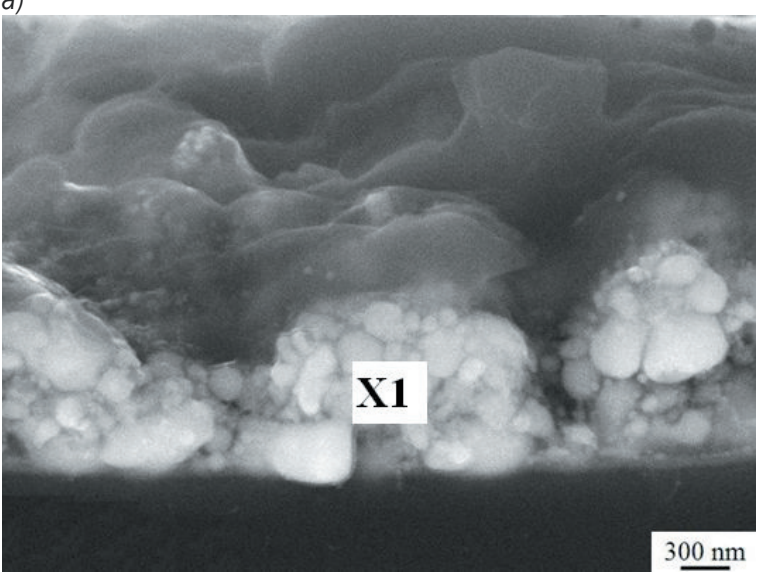

b)

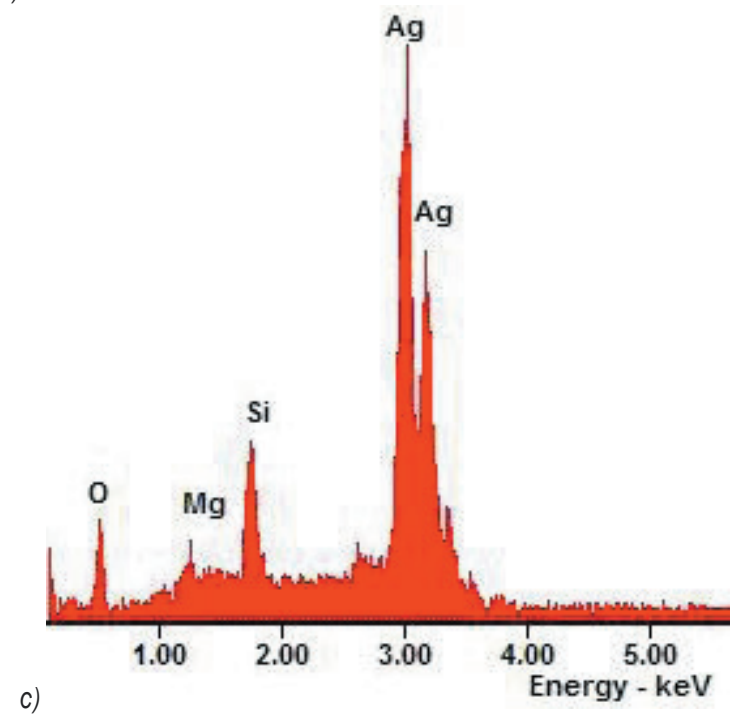

Fig. 12. Images of front electrode system I layer from paste $A$ onto Si substrate without texture or ARC layer by laser micromachinining; a) topography image (SEM); b) fracture image (SEM); c) EDS spectra from $X 1$ area

Fig. 13. X-ray diffraction pattern of front metallization performed from PV 145 paste onto 
silicon surface and co-fired in temperature 830 to $920{ }^{\circ} \mathrm{C}$ (where A means solar cells with different morphology)

\section{SUMMARY}

Based on the investigation results, the following optimal process parameters for manufacturing the front electrode of silicon solar cells were selected: selection for the composition of nano silver paste $83 \% \mathrm{Ag}+2 \% \mathrm{SiO}_{2}+15 \%$ organic carrier, selection of the median thickness of the deposited layer, laser microtreatment on two test systems - laser beam $37.8 \mathrm{~W}$ and feed rate of passage for the laser beam $50 \mathrm{~mm} / \mathrm{s}$. It was found that the silicon substrate morphology has a huge influence on obtaining a minimal resistance value of electrodes using both methods. It is bigger for the substrate with texture than for the one without texture, which is probably connected with the occurrence empty areas under contacts [8], since the median thickness of the pyramids' textured surface for $\mathrm{Si}(100)$ is in the range from 3 to $9 \mu \mathrm{m}$. The antireflection coating prevents the reflection of rays of sunshine and a loss of energy, as well creates a barrier into the connection zone, which increases the resistance between the electrode layer and the silicon substrate. The thickness of the deposited layer has an influence on the structure of the obtained electrode layer and resistance value of the resistance electrode. It was found that SLS testing of contacts with a median thickness of $35 \mu \mathrm{m}$ presents both well adhering and condensing layers to the silicon substrate The contact layers performed from the PV 145 paste create many homogenous connections with the silicon substrate, while contact layers from the $85 \% \mathrm{Ag}+15 \%$ organic carrier, $88.4 \% \mathrm{Ag}+11.6 \%$ organic carrier pastes create point connections.

\section{ACKNOWLEDGMENT}

This research was financed partially within the framework of Scholarship No 51200863 of the International Visegrad Fund, by dr. Małgorzata Musztyfaga.

\section{REFERENCES}

[1] Gautero, L., Hofmann, M., Rentsch, J., Lemke, A., Mack, S., Seiffe, J., Nekarda, J., Biro, D., Wolf, A., Bitnar, B., Sallese, J.M., Preu, R. (2009). All-screenprinted $120-\mu \mathrm{m}$-thin large-area silicon solar cells applying dielectric rear passivation and laser-fired contacts reaching $18 \%$ efficiency. Proceedings of Photovoltaic Specialists Conference, 34th IEEE, p. 1888-1893.

[2] Glunz, S.W., Dicker, J., Esterle, M., Hermle, M., Isenberg, J., Kamerewerd, F., Knobloch, J., Willeke, G. (2002). High-efficiency silicon solar cells for lowillumination applications. Proceedings of 29th IEEE Photovoltaic Specialists Conference, p. 450-453.

[3] Green, M.A. (2002). Third generation photovoltaic: solar cells for 2020 and beyond, Physic E, vol. 14, no. 1-2, p. 65-70, DOI:10.1016/S1386-9477(02)00361-2.

[4] Dobrzański, L.A., Musztyfaga, M. (2011). Effect of the front electrode metallisation process on electrical parameters of a silicon solar cell. Journal of Achievements in Materials and Manufacturing Engineering, vol. 48, no. 2, p. 115-144.

[5] Vitanov, P., Goranova, E., Stavbrov, V., Ivanov, P., Singh, P.K. (2009). Fabrication of buried contact silicon solar cells using porous silicon. Solar Energy Materials and Solar Cells, vol. 93, no. 3, p. 297-300, DOI:10.1016/j.solmat.2008.10.015.

[6] Dobrzański, L.A., Musztyfaga, M., Drygała, A., Kwaśny, W., Panek, P. (2011). Structure and electrical properties of screen printed contacts on silicon solar cells. Journal of Achievements in Materials and Manufacturing Engineering, vol. 45, no. 2, p. 141-147.

[7] Hamer, D.W., Biggers, J.V. (1976). Technology of SelfContained System, WNT, Warsaw. (in Polish)

[8] Panek, P. (2006) Modeling the structure of porous silicon in aspect electrical and optical properties solar cell, PhD Thesis. Institute Library of Metallurgy and Material Science of Polish Academy of Sciences, Krakow. (in Polish)

[9] Goetzberg, A., Knobloch, J., Voß, B. (1994). Crystalline silicon solar cells, John Wiley and Sons.

[10] Dobrzański, L.A., Musztyfaga M., Drygała, A., Panek, P. (2010). Investigation of the screen printed contacts of silicon solar cells from Transmissions Line Model. Journal of Achievements in Materials and Manufacturing Engineering, vol. 41, no. 1-2, p. 57-65. 